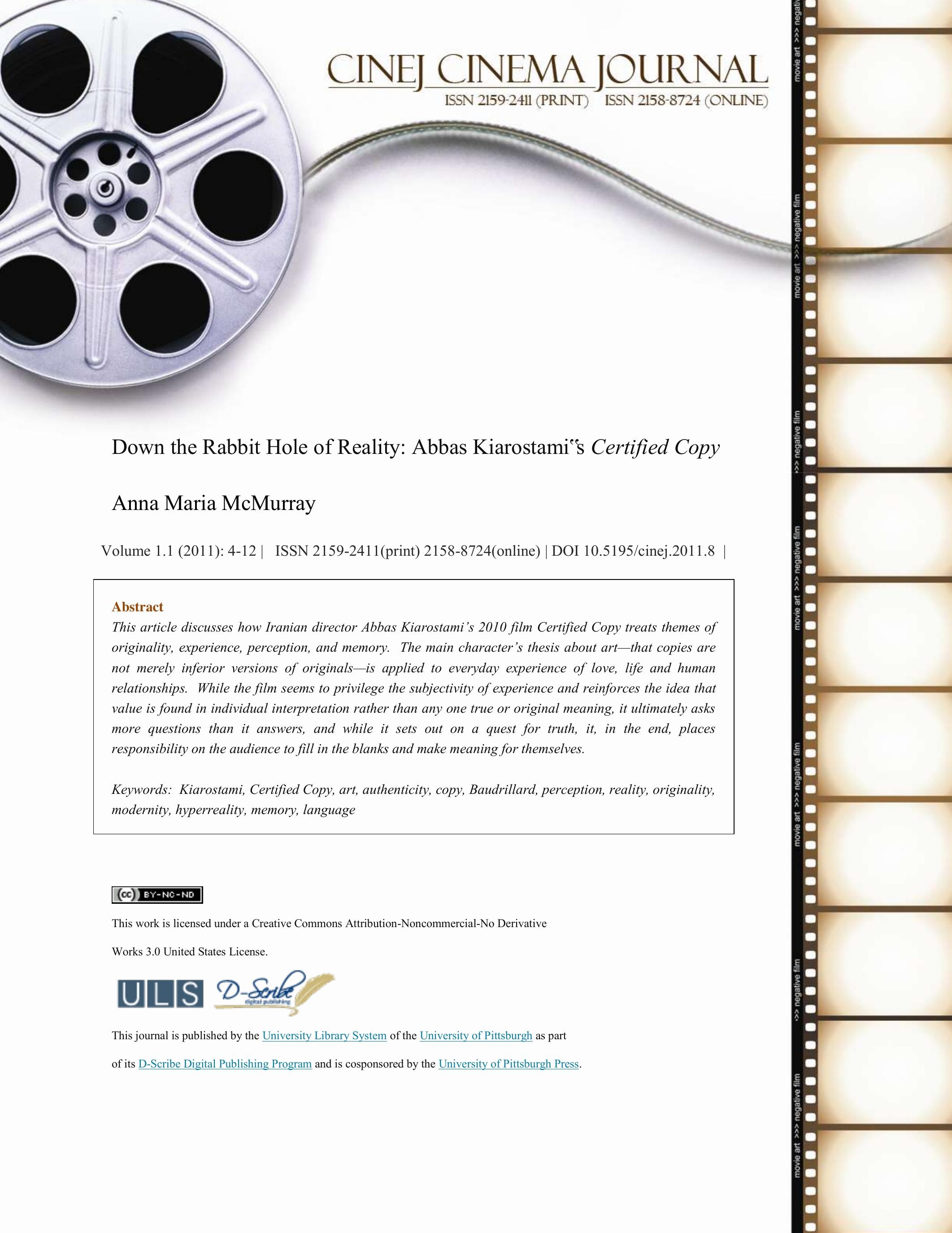




\section{Down the Rabbit Hole of Reality: Abbas Kiarostamies Certified Copy}

On a recent trip to Skopje, Macedonia, some friends and I visited a typical small nightclub on what initially appeared to be a $90^{\text {'s }} \mathrm{s}$ grunge rock theme-night (everyone wore the appropriate attire: heavy boots, black net tights, baggy tops with hole thumbs, and plenty of black smudgy eye makeup). What I soon discovered, though, is that this was not a theme night at all, at least not in the American ha-ha-I-am-pretending-to-enjoyoutdated-music-and-fashion-and-therefore-being-ironical sense. These young people seemed sincere, both in their dress and in their appreciation of the band, which pumped out Macedonian-flavored covers of Pearl Jam and Stone Temple Pilots all night long. The feeling of suddenly finding myself outside of the irony and layers of smirky sarcasm that color so much of American culture was refreshing. In other words, it wasn't the music itself so much as the way in which the music was being presented and perceived that I was appreciating. Of course the cover songs were just that - covers - what some might call inferior copies of the originals - the original sound, tone, setting, and mood of the music having passed us by -if, that is, it is even possible to recall the original context of the music. Do any of us have access to the original version? Isn't all experience and memory of experience by nature individual and therefore tinged by individual perception? I was reminded of all of this while watching Iranian director Abbas Kiarostamies new film Certified Copy (2010), not because the film concerns 90"s rock music (although in some ways, it could), but because the film plays with (play being an important conceit in the film) similar philosophical questions of originality, experience, perception, and memory.

Set in Italy, the film - and be warned, you can't really discuss the film without spoiling the surprise of the plot-begins with a book tour talk of the male lead character"s recently published book „Certified Copy"e, which posits that copies of artworks are not necessarily less praiseworthy than the originals. The British author, James Miller (played by William Shimell), questions the idea of originality, pointing out that even Mona Lisa"s smile may have been a performed smile, prompted by da Vinci. All of this is discussed in detail between the author and his female counterpart, Juliette Binoche (a French antiquities dealer who goes unnamed in the film, but following in the steps of previous critics, I will call her Elle), who has taken a peculiar interest in the author, set up a date, and is now driving him around Tuscany. James"e argument about art is the impetus for their dialogue, which runs the gamut from art and authenticity to Elle"s sister and her sister"s stammering husband, to childrearing and personal responsibility, to love and marriage. The fabric that weaves it all together is the question of what is real and what is simulation, what is of value and what is just for show. This philosophical investigation is not a new one, of course - it is the same question posed by Jean Baudrillard in his 1981 Simulacra and Simulation, where he claims that the postmodern world of signs and symbols forms a kind of simulated reality in which all original meaning is lost. His ultimate example is Disneyland, where illusion and make-believe worlds are meant to distract us from the fact that there are no real versions of these worlds. "The real," as he defines it, "is not only that which can be reproduced, but that which is always already reproduced: the hyperreal." In the world of the hyperreal, Baudrillard argues, all "reality" comes to us already pre-prepared (think Fox News and "reality" television); the representation has replaced the real.

Andy Warhol plays with a similar idea in his well-known 1962 painting Campbelles ,Soup Cans representation and repetition of the familiar soup brand leads us to question mass consumption and the existence of authenticity/originality in art. In the film, a joke about a genie, a desert island, and an everlasting bottle of Coca-Cola turns into a conversation which references Andy Warhol and artist Jasper Johns, both of whom used popular images and icons such as the Coca-Cola brand in their work. In both cases, it is the way in which you regard the ordinary object (in this case, a Coca-Cola) which changes its value. If all of this sounds a little academic and snooty, at least it is rooted in a very real and earth-bound representation of human relationships. In 
a discussion concerning Elle"s sister"s stammering husband, for example, whom Elle deems "simple," James points out that as in art, people may be merely who you perceive them to be. "The way that she looks at her husband," he says, "changes his value."

Ultimately, what the film seems to be asking is: can originality in life and art even exist? Doesn't all art somehow draw on or appropriate parts of what has come before it? One has only to look at genre fiction to see the ways in which most novels operate by simple cookie-cutter formulas. And now, thanks to today's digitallydriven, cut-and-paste world, almost anything can be readily viewed, copied, borrowed, and re-appropriated. The question may not be whether the copy contains real value (it has long been valuable) but what comes after the worship of the copy. In Reality Hunger, his "manifesto" on art, reality and plagiarism, David Shields aptly borrows from William Gibson"s "God"s Little Toys" on the subject: "Copies," he notes, "are no longer cheap but free and flow freely everywhere. . . . Copies have been dethroned; the economic model built on them is collapsing. In a regime of superabundant free copies, copies are no longer the basis of wealth. Now relationships, links, connection, and sharing are. Value has shifted away from a copy toward the many ways to recall, annotate, personalize, edit, authenticate, display, mark, transfer, and engage a work." From Shields "viewpoint, everything is a little bit plagiarized, experience is always subjective, truth is questionable, and reality is never real—claims which, I argue, Kiarostamies film also seems to support.

Like Shields, Certified Copy questions our basis for understanding reality. As the conversation between James and Elle turns to prodding and bickering, it soon becomes apparent that the strangers seem more like a longtime married couple, and indeed, when a coffeehouse local mistakes them for one, they begin to play as if they really are - or are they playing? We begin to wonder if this is a real couple role-playing a first meeting or if this is a couple of strangers performing a 15 year marriage. Whose reality are we getting here? And does it matter? As the couple share conflicting memories, we are forced to acknowledge the subjectivity of truth. For instance, James $^{\text {ee }}$ recollection (or lack thereof) of their past (real or made-up?) does not match that of Elle"s. Elle claims to remember everything, down to the scent on Jamese pillow in the hotel room they shared on their honeymoon 15 years earlier, while James doesn't even remember the location of the hotel, even as he sits on its steps. In a moment of nostalgia, she points out the familiar view from the window of the hotel room-a view he is meant to recognize - but he doesn't even know which window to look out of. It could be that he doesn't remember because they are really strangers, and they share no history together, but in the end it doesn't matter because Kiarostamiec $s$ point is that even if they are really married, recollections of their past would be strikingly different, anyway. Borrowing from Patrick Duff, Shields also acknowledges that we make our own realities: "To fill in the holes, we turn our memories into specific images, which our minds understand as representing a specific experience, object, or thought. Our past experiences have been dismantled, analyzed, re-collated, and then made ready for imagistic recall. The images we store in our memories are not exact replicas of what we experienced; they're what our minds turn them into. They are what we need to re-create the story, which is the full experience the image represents." James"e argument about art, therefore, is really about much more. He admits as much in the beginning of the film when, during his presentation, he says that his thesis can also be used as an approach into self-inquiry. In other words, reality — as strung together by individual memories — is always molded, copied and reshaped, just as art is.

In order to help illustrate the above point, the film layers multiple realities on top of one another, sometimes presenting one as a reflection of the other. Mirroring, reflection and illusion, in fact, play a big part in the film, both in the plot and the mise-en-scène. Just as we are led to question the value of copy and originality in art, so are we led to question the authenticity of who these characters are, both in and of themselves, and to each other. For example, the film presents us with multiple shots of characters being reflected in mirrors and windows, or being layered between or on top of other reflected images (see Figure 1). 


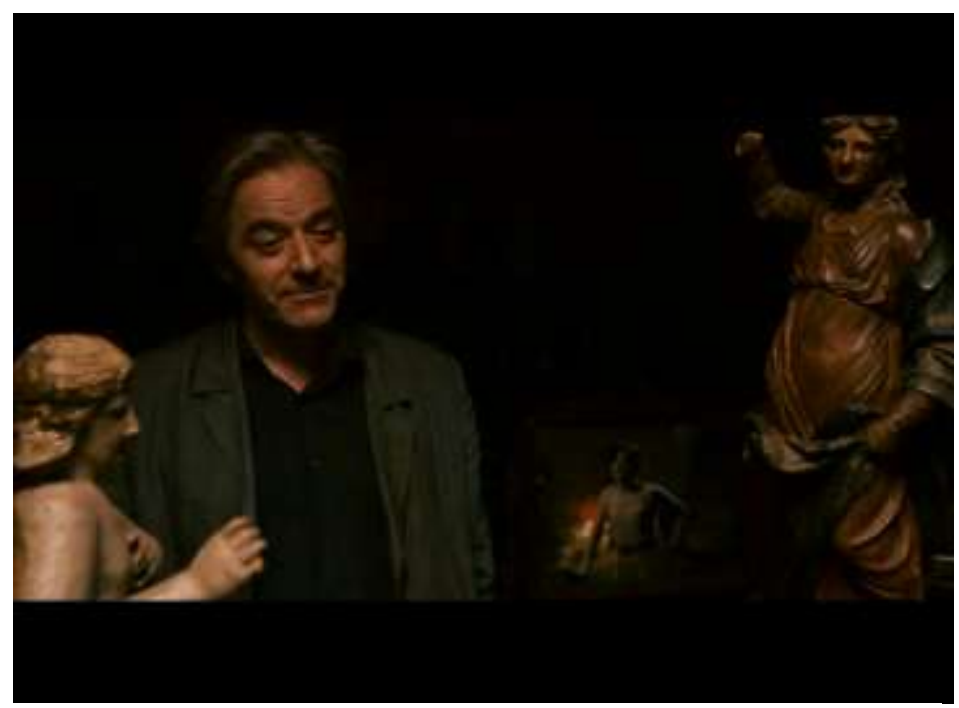

Figure 1: In this scene, set in Elle's dark basement antique shop, James is tightly framed between the very objects he claims to keep his distance from-antiques. An interest in such antiques, he says, can be dangerous, and in this shot, he is literally boxed in by them, as is Elle. Here, he holds a conversation with Elle's miniaturized reflection, reinforcing the idea that we may never really know a person, except through individual perspective. He does not and cannot see the real Elle, only a reflection of her.

There are two memorable scenes in which the two main characters gaze at themselves in mirrors, only when they gaze into the mirror, they are gazing directly into the camera, as if we, the audience, were their mirror image (see Figure 2). In this sense, the film often blurs the line between fiction and reality, destroying the seemingly safe boundary between those being watched (the fictional characters) and those doing the watching (us). Kiarostami often uses full-frontal shots like this in order to give us the feeling that we are also being implicated in the film"s argument. By violating the conventions of film that maintain distance between story and audience, Kiarostami seems to want to destroy the safety zone we so often feel we are in when watching a film. In a particular coffee shop scene, for example, Elle has a conversation about men, women, and marriage with an older local woman as James paces in the background, talking on his cell phone. At one point, the woman, with her back to the camera (and therefore to us), whispers something into Elle"s ear that we are not allowed to hear and then says: "Please keep it secret. They don't need to notice that." We never learn what the secret is, and it is unclear here whether the "they" refers to men in general or to us, the audience. In either case, we, as audience, are no longer in the position of having the kind of privileged knowledge that mainstream film usually offers. 


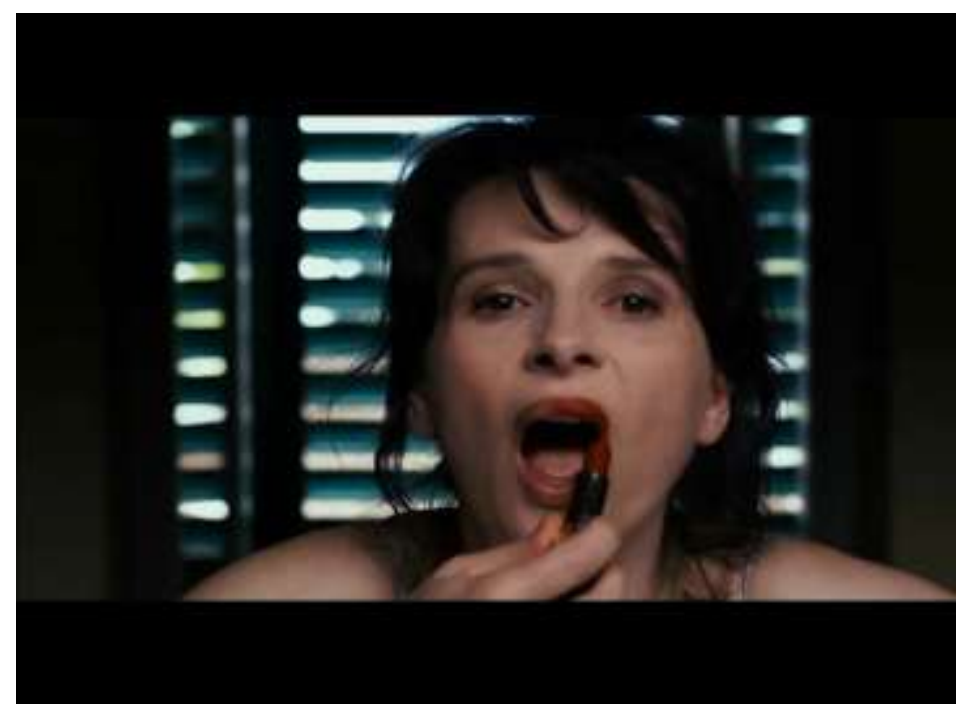

Figure 2: Framed by the window in the background, Elle applies lipstick while looking into the camera (a fictional mirror). It is unclear in this shot who is the object of the gaze - are we looking at her or vice versa?

Violating another convention of film, it is also not clear with whom we are meant to identify. Kiarostami has never been one to be sentimental, and in this film, Elle is annoyingly so (who goes around sniffing pillows in order to imagine a scent left behind long ago?). She also whines and complains a lot. At times, her desperate need to milk James for affirmation comes across as needy and pathetic. But neither can we fully identify with James. He is often arrogant, cold, and selfish. Kiarostami, therefore, never allows us to get too close to the characters. Also, the fact that the characters are often tightly framed by their environment (by mirrors, doorways, windows, etc), reminds us that they are being carefully positioned, much like performers on a stage. This kind of stylized mise-en-scène emphasizes artificiality and objectifies the characters, reminding us that these are familiar personality types and inviting us to imagine someone else (perhaps even ourselves) in their same position (see Figure 3).

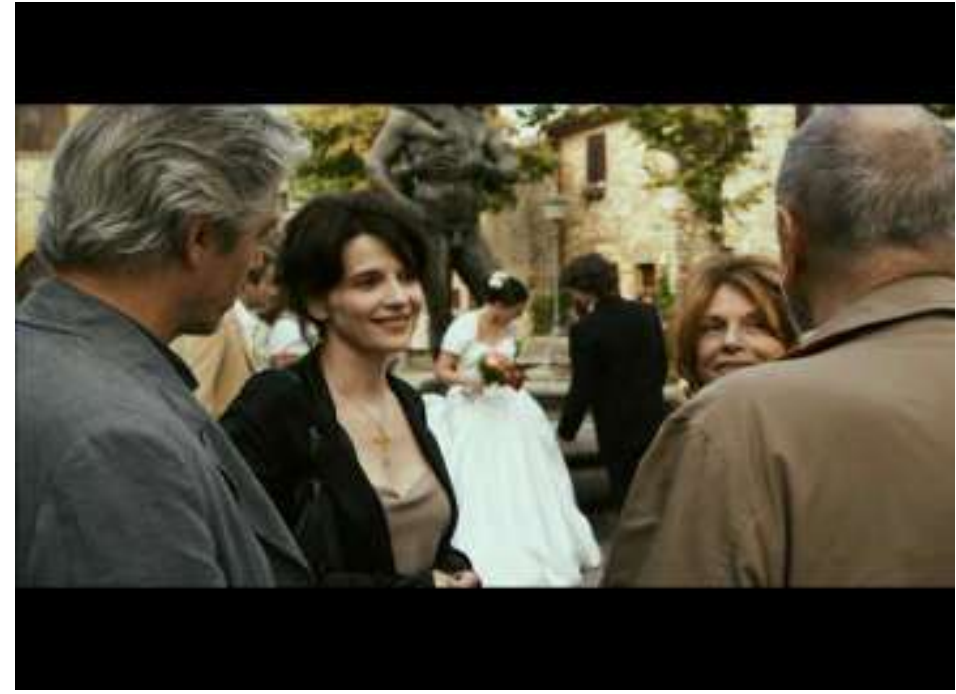

Figure 3: In this closed-form shot, we see three different types of couples: the couple starting out (the newlyweds in the background), the couple in mid-relationship crisis (Elle and James, on the left), and the slightly older, more experienced couple (the French tourists, on the right). The deliberate arrangement of this shot illustrates a familiar life cycle of relationships, each couple representing a different stage in the cycle. 
Along the course of their journey, Elle and James come across several other couples, each in different types of, and in different stages of, romantic relationships: Elle"s sister and her sister"s husband (with whom we don't actually meet but who come up in conversation), a young newlywed couple, an elderly couple leaving a church, and a couple of older French tourists with whom they share a brief conversation. In one case, a young couple looks up to them as an example of a successful marriage; in another, Elle admires the longevity of an older couple"s relationship; and in yet another, the male half of the couple offers familiar advice to James on maintaining a loving relationship. It is as if Kiarostami wants us to see these characters as archetypes, reflections of different kinds of couples, not as entirely unique and original human beings (remember that the film questions the existence of originality in the first place). We see these characters as real people, but also as the personifications of familiar sets of ideas and principles.

As the film progresses, the Baudrillardian argument that everything is a matter of perception, that value lies in representation, not originality, is tossed back and forth as the couple verbally spar their way through the film. In the end, it is not clear who wins. It is also not always clear who is debating which side of the argumentagain, thereby hindering our ability to identify with just one or the other. Elle, the romantic, seems to idealize the conventional notion of what a good marriage is supposed to mean. While sitting in a café, she complains that James is no longer attracted to her. James, on the other hand, believes that what constitutes a successful relationship is merely a matter of perception (at one point, he compares a long-term relationship to a "garden of leaflessness" but wants to stress that a barren garden can also be beautiful). So what that things aren't as they once were, he seems to be saying. His so-what attitude, in fact, mimics that of Elle"s son, who is an integral voice in the film, even though he appears only briefly. In a recap of a previous conversation she had with her son, Elle recounts that when insisting that he come in from the rain because he will get wet, her son responds, "so what?". "You'll catch a cold," she says. "So what?". "You'll die," she responds. "So what?". While Elle stresses the value of personal responsibility, James sees her son as enlightened because he is able to live in the moment and see the bigger picture through the triviality of everyday routine. "Ultimately," James claims at one point, "people must live their lives for themselves." In other words, life, as they say, is only what you make of it.

But even though James de-privileges the authority of a "right" or "authentic" interpretation in art and in life, there are many instances in the film when James mocks the value that others place in everyday sign and symbol. And while Elle claims to value authenticity (she looks down on her sister for liking costume jewelry, for example), there are many instances in which she seems to value the symbol over what the symbol is meant to represent (if there is, indeed, such a thing as original meaning). Always the realist (or pessimist, depending on how you look at it), James finds the ritual and promises of marriage to be illusory, removed from any real or original meaning, even though in his book, he questions the existence of such authenticity of meaning in the first place. Elle, on the other hand, values and respects convention and ritual, sometimes ignoring the meaning behind it. When the newlywed couple asks to take a photo with them for good luck (see Figure 4), for example, it is Elle who insists that they do. Here, she values the representation of the sentiment rather than the reality of the situation - she wants to ignore the real fact that the action would not be sincere, since she and James, at this point, are far from the happy couple the newlyweds assume them to be (if they are, indeed, really a couple). It is the symbol of the thing that is important to Elle, while James sulkily hangs back, refusing to take part in what for him is pathetic and meaningless. Similarly, when Elle puts on dangly earrings and applies red lipstick (another sign heavy in symbolic meaning) in order to please James, he does not even notice the difference. He blows up in a restaurant over what to him, is a stupid ritual of pouring a sip of wine so the customer might taste it first. Elle asks, "Why not try to relax instead of complaining all the time?" But, as previously noted, it is she who does most of the complaining. In all of these cases, James mocks the sign, but, we might ask, if the sign (in this case, the 
wine tasting) itself is arbitrary, then why mock it? Elle recognizes this inconsistency when she accuses James of being a hypocrite for ridiculing her admiration of a particular sculpture. Her point is that even though the thesis of his book is that finding value in art is all about individual perception, he seems to be making a definite judgment about what constitutes "good" or "real" art. In this sense, the film plays with us once again by having the characters switch roles, and we are forced to see the validity (and flaws) in both of their arguments.

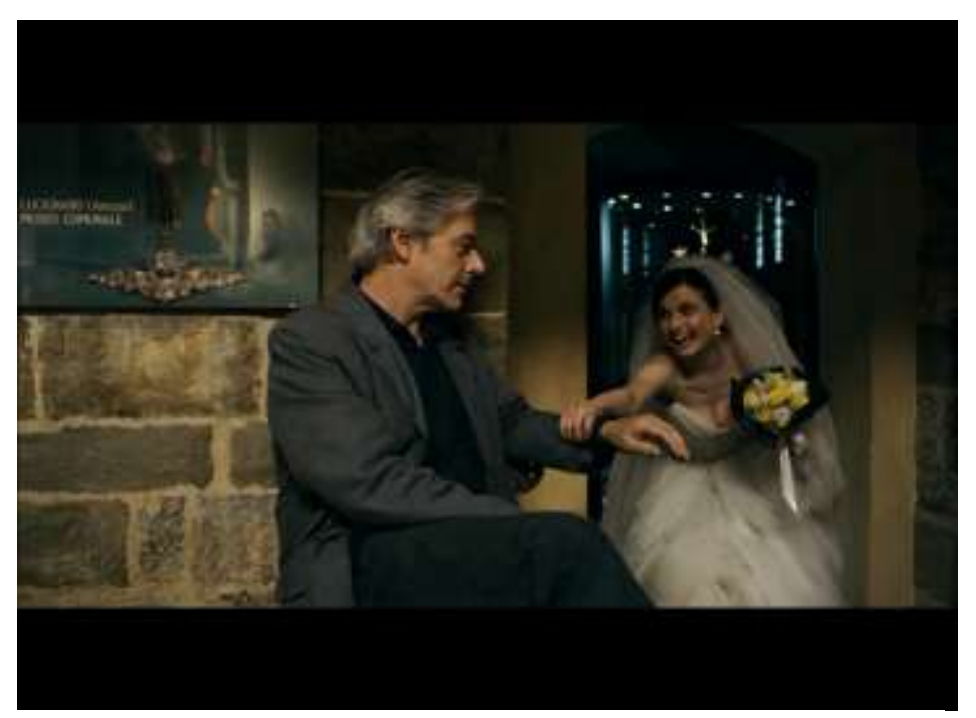

Figure 4: Here, James is once again visually blocked in by what he finds threatening - in this case, the institution of marriage, symbolized by the bride reaching out to pull him into the next room in order to take a photograph and by the mini-reflection of yet another bride in the framed poster just over his right shoulder.

The destabilization of the boundary between sign and meaning, appearance and reality, and copy and authenticity is paralleled in the way the film also destabilizes the institution of language, which is used as an extended metaphor for the two main characters" disparate worlds of belief. In the café scene previously discussed, when the local woman expresses surprise that James does not speak Italian as Elle does (James is fluent only in English while Elle speaks fluent English, French, and Italian), James responds by saying "they [his family] speak their language and I speak mine," pointing out the impossibility of being able to truly understand or identify with another person. Language as metaphor is further illustrated in long scenes during which James speaks in English while Binoche responds to him in French. If the two cannot see eye to eye when speaking the same language (English), how might the difficulty of translation and interpretation exacerbate their conflicts and misunderstandings? Of course this raises the question of whether language, in itself, can ever be a truly effective mode of communication. For Baudrillard, language is often used to manipulate and obscure rather than to reveal. For Saussure, too, "language is form and not a substance," suggesting that the utterance of mere words (which are arbitrary) does not necessarily guarantee a common understanding of such words. Similarly, Derrida argues that the sign is meaningless in and of itself and only acquires meaning through subjective interpretation and the conventions we ascribe to it. In line with this train of thought, what the film seems to be reinforcing, again and again, is that even the seemingly simple connection between word and meaning, sign and signified, is an illusion. "There"s nothing simple about being simple," as James says to Elle in the car. The truth is that we all speak our 
own languages and can only hope to connect with others through singular, sometimes accidental, moments of understanding.

So where does this leave us? If everything is ultimately reproducible, each copy being no less valuable than the original, then what is the point? Where can meaning be found? Is all meaning meaningful? Who or what is responsible for the destabilization of meaning that surrounds us? And how might we effectively communicate in such an environment? For Baudrillard, the continual state of hyperreality we live in is caused by several factors, including urbanization, capitalization, commercialization, capitalism, and the modern world"s worship of money. Kiarostamies films, too, often seem to place blame on the modern world. The protagonist in The Wind Will Carry Us (1999), for example, travels to a remote village to film an ancient death ritual, but as he and his crew encounter a multitude of obstacles as they wait for the subject of their film to die, we are led to question the value of his work, as well as the intrusion of modernity. And the technology of the modern world does not win out, as illustrated when the protagonist (in a series of comic repetition) is forced to jump in his truck and race up a hill to get cell phone service. In Certified Copy, too, there are multiple scenes in which the modern world of cars, motorbikes, and cell phones infringes upon the natural world or interrupts conversation, as in the opening scene when James answers his cell phone during his presentation (in the meantime, Elle's son, who is also in the audience, is playing a videogame). This opening scene establishes a pattern in which the film-length dialogue between the two characters is repeatedly interrupted by cell phone calls. These kinds of modern-day intrusions seem to prevent the characters from truly being able to communicate with or listen to one another.

In its built-in commentary on modern life, the film sets up contrasts between the old and the new. In a scene which also reveals differences between their values and beliefs, for example, Elle admires an old sculpture - she sentimentalizes the past, longevity, and convention - while James gazes longingly at a flashy new motorcycle - he accepts change and newness as a natural part of life. Such examples remind us that even a small village like Arezzo (which might otherwise seem out of place and time), is not without its signs of encroaching modernity: a hamburger joint, a flashy new vehicle parked in front of a historical building, ancient architecture flanked by modern storefronts and ATM machines. This conflict between the natural and modern worlds becomes part of who the characters are, as they travel through and respond to their surroundings, and is illustrated beautifully as Elle and James drive in her car, their faces shadowed by moving reflections of the scenery, people, and architecture they pass (see Figure 5). The setting takes on a life of its own as it both swallows and entraps the characters (see Figures 6 and 7). The active role setting plays in this film, as well as its natural beauty, suggests that even as the hyperreal creeps in, the natural world still insists on making itself known. This does not mean to say that the film is making a sweeping claim concerning nature and modernity, since it avoids such clear-cut truths altogether. Instead, the film offers a variety of possibilities, or ways of looking at the world which overlap (and sometimes run into) each other. The overall effect is a collage of space, place, and identity.

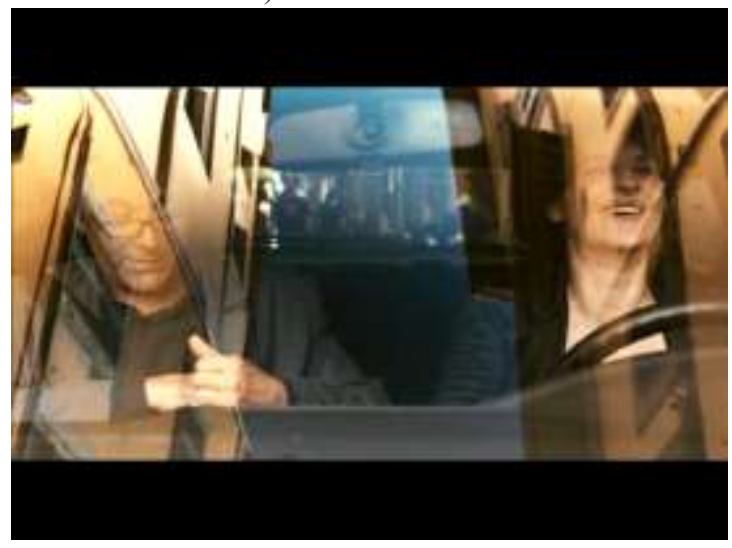

Figure 5: The use of color, reflection, movement, and light in this scene form a kind of palimpsest in which the couple are both literally and figuratively colored by their surroundings. The multi-layered effect creates a visual complexity which echoes the complexity of ideas presented by the plot. 


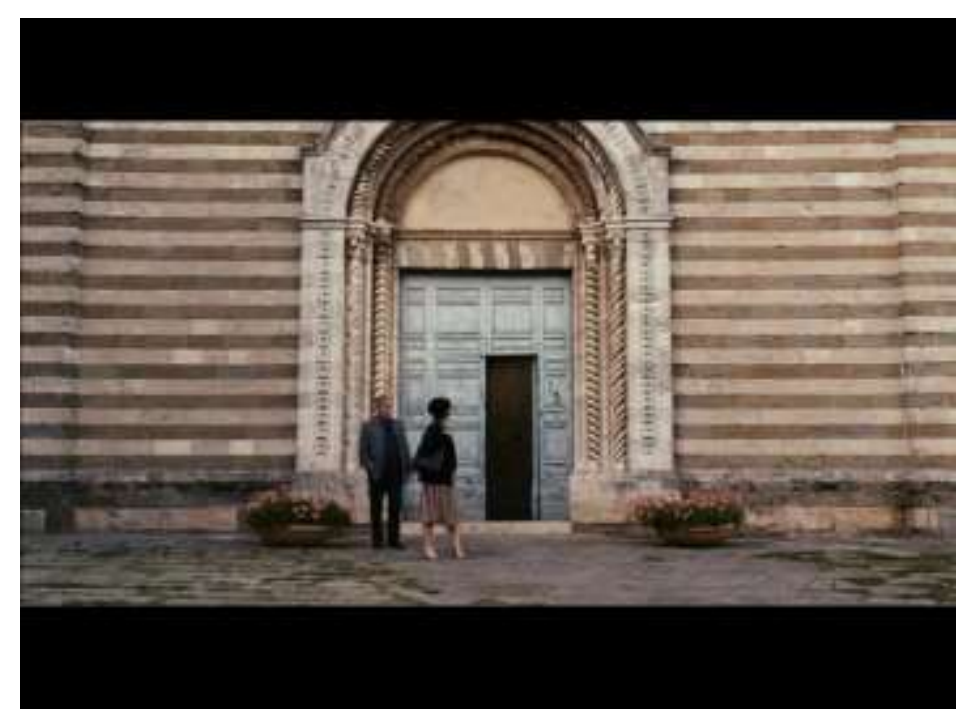

Figure 6: Here, the grandiose setting of a cathedral dwarfs the couple. Their lives and problems, from this perspective, seem small in respect to the wide world around them.

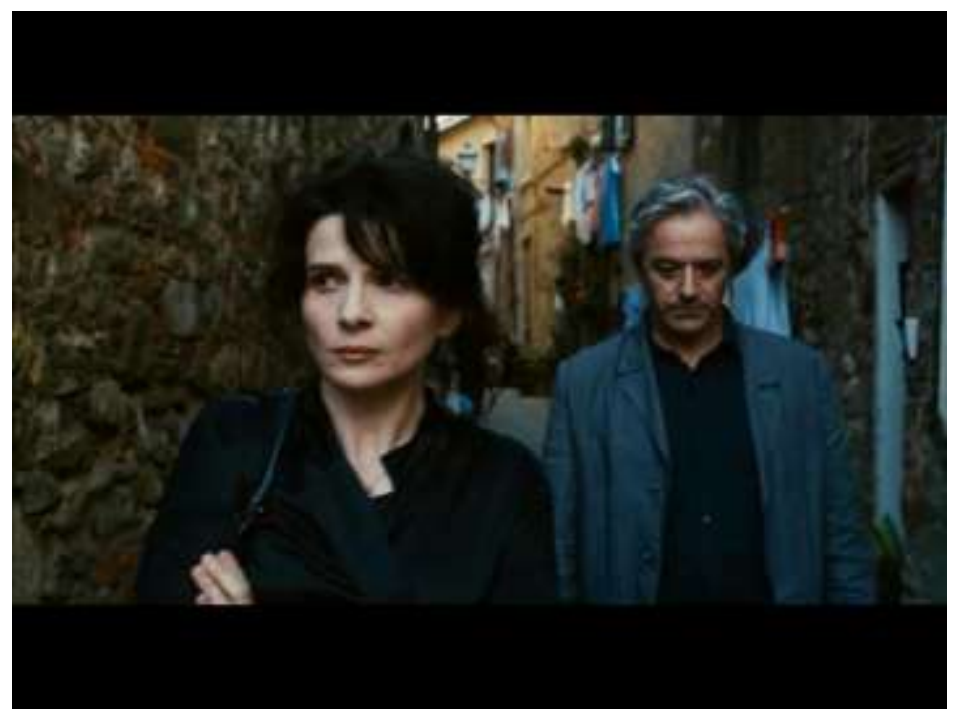

Figure 7: Literally tunneled in by their environment, Elle and James, visibly unhappy with each other, retreat into their own worlds.

In the end, it is unclear just what Kiarostami wants us to take away from this road/mind trip, but his films have never given the audience the satisfaction of closure. Instead, they tend to taunt the audience for wanting it in the first place. At the end of Taste of Cherry (1997), for example, we are abruptly pulled outside of the narrative and shown, documentary-style, the cameras and camera crew, thereby disrupting our relationship with the main character and therefore the story. One thing is clear, though, and that is if a physical journey is indicative of an emotional journey, as it so often is in film, then the couplees trip, even though it is only a half hour by car, is an ambitious one. The film ends with a long take of James silently staring into the hotel mirror (but really into the camera, and therefore, at us) in a prolonged moment of contemplation, a copy of a previous scene of Binoche staring into the mirror of the restaurant bathroom. We don't know what he s thinking, or where this leaves them/us, and we can only fill in the blanks with possibilities, which some may find dissettling. It very well could 
be, though, that this is exactly what Kiarostami wants us to feel. James ${ }^{\text {ee }}$ direct stare signifies a shift in the burden of meaning assumed by the film-as-active/audience-as-passive dichotomy. As in many of his films, we as audience are meant to take the active role, creating meaning for ourselves rather than expecting the film to convey it for us. Whether this has all been reality or some sort of copy of it is not the point - that would be too simplistic. As James states at the very beginning of the film, when it comes to art (and life, the film argues), "there are no immutable truths to fall back on," only different versions of it.

\section{References}

Baudrillard, Jean (1990). Cool memories, vol 1. London: Verson.

----- (1994). Simulacra and simulation. Trans. Sheila Faria Glaser. The University

of Michigan Press.

----- (1993). Symbolic Exchange and death. London: Sage.

Derrida, Jacques (1998). Of grammatology. Trans. Gayatri Chakravorty Spivak.

Baltimore: Johns Hopkins.

Saussure, Ferdinand de (1959). Course in general linguistics. Trans. Wade Baskin.

in Literary Theory: An Anthology, ed. Julie Rivkin and Michael Ryan, 76-90. Malden: Blackwell.

Shields, David (2010). Reality hunger: A manifesto. London: Penguin. 